\title{
Developing Written News Item Text Materials for the Tenth Graders of Senior High School
}

\author{
Sri Muryati \\ SMAN 7 Semarang \\ JI. Untung Surapati Kecamatan Ngaliyan \\ Semarang \\ srimuryati2004@yahoo.com
}

\begin{abstract}
School Based Curriculum or "Kurikulum Tingkat Satuan Pendidikan" (KTSP) 2008 requires teaching and learning activities that should be active, innovative, creative, enjoyable, cheerful and qualified. In order to share or help teachers, this Research and Development (R\&D) research was conducted that may inspire them in developing teaching and learning materials for the expected class. The scope of this study is developing written news item text materials for the ten graders of senior high school so that the students are able to create a simple short news item texts which are classified into four kinds: straight, interpretative, investigative and color news stories. The method used was adapted and adjusted from Hyland's Model of material development. The process started from doing a survey, followed by developing materials, having experts and teachers validation, doing first revision, trying out, writing second revision, and producing final result. The try out resulted student average score 76,14 that means the students achieved 79,55 \% above minimum national learning mastery, 75. This study focuses on the written news item texts from the 3 sources, namely newspapers, magazine and internet. Since the three sources are available in one source, the internet, the final product is entitled '3 News in 1" accompanied by Interactive Self-study VCD'.
\end{abstract}

Keywords: $R \& D$, News Item Texts, Teaching And Learning Materials 


\begin{abstract}
Abstrak
"Kurikulum Tingkat Satuan Pendidikan" (KTSP), 2008, mensyaratkan proses belajar mengajar yang aktif, inovatif, kreatif, menyenangkan, gembira, berbobot.Untuk berbagi dengan atau membantu guru, penelitian Research and Development (R\&D) ini mungkin memberi inspirasi mereka dalam pengembangan materi pembelajaran seperti kelas yang diharapkan tersebut. Ruang lingkup penelitian ini adalah untuk mengembangkan materi teks berita tertulis bagi kelas $\mathrm{X}$ sekolah menengah tingkat atas agar siswa dapat membuat teks berita singkat yang diklasifikasikan dalam empat jenis: straight, interpretative, investigative dan color news stories. Metode penelitian yang digunakan diadaptasi dari model pengembangan materi Hyland. Proses penelitian dimulai dari melakukan survei, yang diikuti dengan pengembangan materi, validasi oleh guru dan ahli, revisi pertama, uji coba, revisi kedua, dan menyusul hasil akhir. Uji coba menunjukkan angka rata-rata 76,14 yang berarti $79,55 \%$ diatas angka criteria ketuntasan minimal, 75. Penelitian ini fokus pada teks berita tertulis dari tiga sumber, yaitu koran, majalah, dan internet. Dikarenakan ketiga sumber tersebut di dalam satu materi, internet, produk akhir disebut "3 berita dalam 1" yang dilengkapi dengan VCD interaktif untuk belajar sendiri.
\end{abstract}

\title{
Kata Kunci: $R \& D$, Teks Berita, Materi Pengajaran Dan Pembelajaran
}

\section{Introduction}

Although the school based curricula has been implemented since the academic year of 2006/2007, most teachers find it difficult to prepare their complete teaching kits. Indeed, the regulation looks so challenging, yet the teachers have not much time for preparing it. Furthermore, they sometimes feel unsuccessful in implementing the concepts that they have into practices. On the other hand, the students need something interesting, enjoyable, and challenging learning process. It includes the learning material. It is contradictory with the monotonous 
material that they have got. Nowadays, we as teachers should be aware of this urgent case. The learning material must be selected and revised into the more inovative ones.

The students are treated as subjects while the teachers' function as facilitators of the teaching learning process. In the process of the teaching and learning, text book is very important. Its existence needs improvement to be always updated, especially the standard material that be one of the central pillar of a text book. Accordingly, there are so many text books sold out in the market, whereas not all of the books cover the material which are based on Standard of Competences (Standar Kompetensi) and Basic Competences (Kompetensi Dasar). Teachers at school have more than one textbook for teaching. In choosing a textbook, a teacher has his or her own criteria though some are unqualified. There are some books chosen by him or her only because of their low prices. Conversely, there are some good books that are sold unsatisfactory because of unfamous publisher and sometimes the students cannot afford it. In facing this circumstance, teachers as the facilitators, should facilitate the teaching- learning process by using additional material or media. This will help them do the communication with their students.

Based on the writer's experience in teaching, in order to make the process of teaching and learning more interesting, enjoyable and challenging. She uses instructional media to make the progress of instructional purposes more effective and knowledgeable. They are applied through hardware and software. In this study, their applications will be used in the form of Video Compact Disk (VCD) as hardware and Microsoft Power Point 2007 as software which present animation, colour, 
movies and sound. In addition as supporting programs, she uses Ulead 3D Cool Studio, VCD cutter and Macromedia Flash.

In developing material that will be a part of a text book, she should be aware of what materials she is going to choose. Developing materials of news item is chosen because it relates to students'daily lives. By using news item texts, they will get knowledge and information from all over the world so that they are aware of developing their interest of reading and writing in English both through printed and electronic media (internet). Besides, news item is stated in the curriculum for grade ten semester two.

Although the students have been taught to produce texts since they were in junior high schools, the activity of producing a text that is created by the students in Indonesia seem meaningless and disorganized eventhough they have studied grammar from the first time they learn English. Richards (2001:4) claims that the goal of language learning is communicative competence. Learners learn a language through using it to communicate, so does in communication by using texts. Hence, in creating a good text, the students need more practice in order to produce it as a medium of communication.

The scope of this study will be news item text in the form of written material. It is available in the Content Standards which explain that the scope of English Subject in SMA/MA contains the ability of knowing and creating short functional texts and monologues as well as essays. One of the text types is news item text. The gradation of the materials are taken from the use of vocabulary, grammar, and rhetorical steps. 
To face the reading and writing situations of teaching-learning processes, the material development is formed by making a concept of scaffolding in order to create good collaborations between teacherslearners. Some models of developing material have been discussed by some researchers. One of them was by Hyland (2003:57) stating nine stages of material development. They are: (1) consideration of the students, (2) consideration of learning context, (3) consideration of the target context, (4) establishment of course goals and objectives, (5) planning the syllabus, (6) devising units of work and lessons, (7) creation or evaluation and selection of materials, (8) teaching the course, and (9) evaluation of learners.

The adapted and adjusted model of material takes the some steps. Firstly, the first six steps of Hyland's model (consideration of the students, consideration of learning context, consideration of the context, establishment of course goals and objectives, planning the syllabus, and devising units of work and lessons) are simplified into one step i.e. doing a survey. The second step (creation or evaluation and selection of material) is simplified into one step i.e. developing material. Next, two steps are added as steps 3 and 4 before teaching the course, experts and teachers validation and doing first revision based on the validation. The validation from the experts and teachers are considered necessary to see whether the material has already met the criteria.

Then the eighth and ninth Hylad's steps (teaching the course and evaluation of learners) are simplified as trying out. Finally, as the last two additional steps, the doing second revision based on the tryout is 
necessarily conducted to improve the material before it comes to producing the final products.

The consideration of the students was made based on the curriculum that the text type news item is a compulsory subject for the ten graders of S.H.S. semester 2. The consideration of learning context and the consideration of the target context were made based on the need analysis in the form of questionaires given to the ten graders of S.H.S. and a teacher who was also teaching them. It was also based on the Informational Level of literacy (Celce-Murcia et al., 1995:6 in Agustien, H. I R.,2003:31). In informational level the learners are able to use English to access accumulated knowledge and use English in informal and formal contexts. This level is in line with the competence standard stated in the school based curriculum which is now being implemented at senior high schools in Indonesia.

This study presenting the material development of news item (CBC, 2004) is a text that has the following elements: social function, generic structure, and language features. Firstly, the social function/communicative purpose of a News items is: to inform the readers, listeners or viewers about an event of the day, which is considered newsworthy or important. Secondly, generic structure comprises (1) newsworthy events: recounts the event in summary form, (2) background event : elaborate what happened, to whom, in what circumstances, (3) source: comments by participants in, witnesses to and authorities expert on the event. Then langauge features consists of short telegraphic information about: story summerized in one sentence, use of 
material processes to re-tell the story, use of projecting verbal processes in source`stage, focus on circumstantial meaning.

Dealing with this challenge of planning to assess writing reports for their students, teachers need to be aware of a variety situations that will happen in the pedagogical implications during teaching-learning processes. There are criteria that will be used to construct them. (Schmitt \& Messick (1989) in Richards (2001:15-16): Validity (did the test really mesure what it was supposed to measure?), Reliability (did the past test perform consistently from one administration to the next?), Practicality (was the test practical to give and mark in particular setting?)

According to the statements above, this study will present final assessment in the forms of multiple choice and writing essay (written news item text) as psychomotoric score. For the multiple choice, the test items contain news item texts that will be analysed in terms of generic structure, language features such as past tense, punctuations, capital letters and comprehension. While in the essay, students are required to create a news item text by choosing one of available topics taken from one of the events of the day. Students' answers sheets consist of scoring columns are ready at once.

\section{Research Methodology}

This research used research and development (henceforth R \& D) approach, since the objectives of the study are to develop and innovate news item text material for the ten graders. Principally, the objective of $\mathrm{R} \& \mathrm{D}$ approach is managing and developing the effectiveness of products applied at schools. This is started from administering an 
observation that is valuable in deciding what material will be developed and on what grade the material will be consumed. The R \& D process has been constructed in developing written news item material for the ten graders of senior high school.

In developing written news item texts material using $\mathrm{R} \& \mathrm{D}$, this research applied the adapted Hyland's model of material development as stated in introduction part. The process of material developments were categorized into three stages. The first stage was need analysis by giving questionaires about the existing material used for the students. Furthermore, teachers conducted a survey comprised: (a) mapping standard of competences, basic competences, text-types, and number of meeting taken from Content Standard and the accessible syllabus; (b) making Syllabus; (c) making lesson plan. The second stage was developing material, i.e. adapting, modifying, altering or simplifying the existing material linked with written news item text. The next process was competent experts and teachers validation on the developed draft product (the mapping, syllabus, lesson plan, a student book, a teacher guide, and Self-Study VCD as the result in developing the material). By referring to the validation forms of the experts and teachers, the writer did a revision. Next action was trying out upon the developed product. In the tryout of the material, the last two steps in Hyland's model (teaching the course and evaluation of learners) were combined. Then if there were still improvements after the tryout, she did second revision. For the last extra step, the writer closed all of the steps by producing the final product of the study. The dissemination of the final product is distributed through 
Subject Teacher Forum or "Musyawarah Guru Mata Pelajaran"(MGMP).

\section{Discussion}

As the research design above, the discussion display the impelemented stages.

\section{The result of doing a survey through mapping}

By doing a survey through the mapping of Content Standard and collaborating with official educational calender, this study of developing materials was presented in written news item text notably for reading and writing skills. Afterwards, the mapping process was persisted by formulating the syllabus and lesson plan based on the Standard of Competences and Basic Competences. The syllabus which was centred on the Content Standard was compiled on the standard of competences and basic competences, instructional materials, learning activities, indicators, evaluations, time allotment, and sources.

The lesson plan of this study consisted of an identity of the subject, the standard of competences and basic competences, themes, subthemes, teaching methods, objectives, materials, meeting activities, evaluations, and final assessments. The additional contents were scoring rubric of writting assessment of a news item text.

\section{Developing materials of written news item text}

The Materials were developed into a product that consisted of the student book, teacher's guide (including teaching procedure and answers key), and Self-study VCD as a supplement. Written texts were adapted/ 
modified from three mostly sources newspapers, magazines and internet and some events suitable with the students' environment (including at school and home).

After the drafts of material development were gathered, they were systematically arranged based on reading-writing activities. The reading and writing sections were presented in stages (Building Knowledge of the Field (BKoF), Modelling of the Text (MoT), Joint Construction of the Text (JCoT), Independent Construction of the Text (ICoT)). However, before exploring more, readers would be brought into the plot of the material through 'mind mapping' that contained of the Standard of Competences, Basic Competences of curriculum, and indicators : (1) language literacy,(2) language feature,(3) socio culture, (4) discourse competence, (5) Learning Strategy (Celce-Murcia et al,1995:10). Building Knowledge of the Field (BKoF)

The stage of BKoF was handed over into the introduction of news item text type to students for the first time. Here, they learned the basic idea of news item text. The discussion about the contributions of the text were started with the significance of a news text and its types. It discussed its social functions, generic structures, items and language features. The students browsed their mind everything that would be parts of a news item text by using simple words.

In unit 1, the discussion about"Do You Like Reading News stories"? for the shake of attractiveness, was modified into "Build Your Reading Knowledge". In this stage, there were some goals should be covered in learning the materials: (a) share the content of written news item material and (b) the elements in a news item text. 
In unit 2, the BKOF of "How do You Write News Stories?" wasmodified into "Build your writing Knowledge!" In the first stage of writing skill, students reviewed and studied the language features. Firstly, Grammar Focus 1: Pronouns. They covered the concept of pronouns, for examples kinds of pronouns and their usages. After the teacher's explanation they were asked to continue to student's worksheet 5 and 6 comprising of Memory Games and Crosword Puzle. Secondly, Grammar Focus 2 : Process. They covered the concept of process, for instance kinds of process and their usage. After the teacher's explanation, students were asked to classify the processes in a certain text.

\section{Modelling of the text (MOT)}

In this stage, they paid attention to teachers' explanation in applying the social functions, generic structure, and language features into news item texts. This activity was followed by the students who practice putting them in some exercises.

MOT was modified into "Have a look at these Models of News Item Texts" in Section 2. In the stage, students were supposed to get the models of news item texts. In addition, the students in the phase of writing skillswere given other model of news item text to be classified the processes into material, mental, relational, verbal, or behavioral.

Meanwhile, continuing the previous grammar focus, grammar focus 3 discussed about simple past tense. It covers the concept of past tense, examples, and their usage. Grammar focus 4 consisted of past continuous tense covers the concept of past continuous tense, examples, and their usage. Grammar focus 5 was past perfect tense covering the concept of past perfect tenses, examples, and its usage. 
Joint construction of the text (JCOT)

In JCOT, students began to contribute in constructing whole type of news text. Teachers reduced dramatically their contributions in constructing the news item text. Here, the students got closer to create the text-type independently.

By doing the stage in group, students wrote writing section in a different way. It is represented into the wheel process (Harmer, 2004:6) below:

Figure 1.

The wheel process

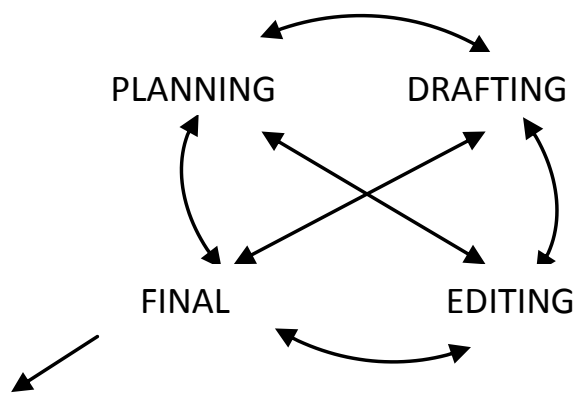

FINAL VERSION

The 'final versions' mean, students in group may produce their final version once. If there is still an error, the other group will do reediting this first version. The students could combine their draft with the revised version before writing their second final one. This stage is group presentation / publication activities.

In the research, JCOT is modified into "Do it in Groups!" in section 3. In this stage, the students studied the elements of news item, social function, generic structure and language features. Afterwards, they 
identified the parts of news item that covered all the elements above. To reinforce the students' understanding about it, they were asked to analyze other news item text provided in the students' worksheets done using some games.

\section{Independent construction of the text (ICOT)}

In this stage, Feez and Joyce (2002:31 in Depdiknas,2009:313) states that students work independently to create the text and learner performances are used for achievement assessment. Making concept or drafting is merely done by students who have had higher level brain waves. Hence, news item texts made by students may be discussed with teachers or other writers. For the very first time, they possibly looked at dictionaries or thesaurus for new vocabulary but not in writing their final assessment.

This study modified ICOT into "Do it individually!" in Section 4. In this stage, students were expected to analyze the news item text individually. This stage ended by asking the students to find any latest news whether it was from news paper, magazie or internet then analysed it based on the generic structure of news item, action verbs e.g hit, run and saying verbs e.g tell, say.

In the beginning of fourth stage of writing skill, the students were asked to continue their work on worksheets to write their coverage based on the correct generic structure of news item individually, followed by the evaluation in Unit 3. The evaluation consisted of 35 items of multiple choice test and 5 items of essay test. 


\section{Experts and Teachers Validation}

In developing written news item text material, there were three experts and two English teachers who did validations. The experts were: Dr. Dwi Anggani L.B. M.Pd, Glenn A McGrew II, Resti Budianti, S.Pd, and Agus Triarso,S Kom and the English teachers are: Suharno, M.Pd, Budhi Setiawati, M.Pd.

The results of the validation are as follows:

\begin{tabular}{|l|c|c|c|c|c|c|}
\hline \multirow{2}{*}{ PRODUCT } & \multicolumn{5}{|c|}{ THE AVERAGE OF VALIDATION } \\
\cline { 2 - 6 } & \multicolumn{2}{|c|}{$\begin{array}{r}\text { EXPERTS/ NATIVE } \\
\text { SPEAKER }\end{array}$} & \multicolumn{2}{|c|}{ TEACHERS } & AVERAGE \\
\cline { 2 - 6 } & 1 & 2 & & 1 & 2 & \multirow{2}{*}{} \\
\hline $\begin{array}{l}\text { Student's } \\
\text { (work)book }\end{array}$ & 3,40 & 3,33 & & 3,80 & 3,60 & 3,46 \\
\hline $\begin{array}{l}\text { Teacher's guide } \\
\text { Multi Media of } \\
\text { Self-study VCD }\end{array}$ & 3,60 & 3,20 & & 4.00 & 3,60 & 3,40 \\
\hline
\end{tabular}

\section{Doing first revision}

In accordance with the experts comments, judgments, suggestions, and the need analysis, the first expert viewed the language of the syllabus and mind mapping which consisted of standard competences and basic competences. The first expert suggested that the competencies should be better written in the original Indonesian version. The learning activities in the syllabus were revised from teacher to student centres. 
Besides, the first expert approved the product, but there should be little improvement on typing or spelling, grammar and the news topic that must be closer to the needs and interests of the students. It was necessary to have a need analysis questionaire on topic or interest. The second expert suggested (1) to present the materials in a different frame, so that users would not too exhaust because of many posts in one view and (2) to provide right or wrong responses. The exercises should not only "click and drug", but it could be also in the form of "click and click".

\section{Try out and its discussion}

The preparation of the try out

Based on the agreement between the researcher and the headmaster, the try out would be conducted by the teacher of grade ten in the school. The reason was that the students did not need much time to adapt to new teacher. Then, the writer showed the material which was prepared in a student book, a teacher's guide, and Multimedia Self-study VCD and let the teacher read the syllabus and lesson plan. The teacher might leave any material that seemed too complicated for 10th graders. By doing a simple random sampling, the tryout was performed in one class, selected from 10 classes that were labeled by using alphabets $X_{1}$ to $\mathrm{X}_{10}$.

The try out

Considering the time allotment, the tryout was conducted in five days, 90 minutes per meeting. During the tryout of the material, the 
teacher did not use Multimedia Room at school. This facility is not only used by the English teachers but also by the other subject teachers. In addition, by using the regular classroom, both the teacher and the researcher flexibly did any demonstations, group works, or outdoor movements. The tools needed for the tryout were prepared by the researcher.

\section{Evaluation}

In 29 May 2010, the students did final assessment. This assessment consisted of two sections. First was written test which was composed into multiple choice and essay forms. There were 35 multiple choice items and 5 essay (written in 90 minutes)

The result of the students' answers on the Materials based a questionnaire was:

\begin{tabular}{|c|c|c|c|c|c|}
\hline $\begin{array}{l}\text { Grade } \\
\text { Criteria }\end{array}$ & $\overline{\mathrm{A}}$ & $\bar{B}$ & $\bar{C}$ & $\bar{D}$ & $E$ \\
\hline $\begin{array}{l}\text { Harmonious } \\
\text { materials }\end{array}$ & $\begin{array}{c}2 \\
5 \% \\
\end{array}$ & $\begin{array}{r}32 \\
80 \% \\
\end{array}$ & $\begin{array}{c}5 \\
12.5 \% \\
\end{array}$ & $\begin{array}{c}1 \\
2.5 \% \\
\end{array}$ & $\begin{array}{c}0 \\
0 \% \\
\end{array}$ \\
\hline $\begin{array}{l}\text { Conceptions, } \\
\text { Clarity of } \\
\text { explanations }\end{array}$ & $\begin{array}{c}2 \\
5 \% \\
\end{array}$ & $\begin{array}{c}30 \\
92.5 \% \\
\end{array}$ & $\begin{array}{c}1 \\
2.5 \% \\
\end{array}$ & $\begin{array}{c}0 \\
0 \% \\
\end{array}$ & $\begin{array}{c}0 \\
0 \% \\
\end{array}$ \\
\hline $\begin{array}{lr}\text { Clarity } & \text { of } \\
\text { instructions } \\
\text { exercises }\end{array}$ & $\begin{array}{c}0 \\
0 \% \\
\end{array}$ & $\begin{array}{c}39 \\
97.5 \% \\
\end{array}$ & $\begin{array}{c}1 \\
2.5 \% \\
\end{array}$ & $\begin{array}{c}0 \\
0 \% \\
\end{array}$ & $\begin{array}{c}0 \\
0 \% \\
\end{array}$ \\
\hline Writing steps & $\begin{array}{c}8 \\
20 \%\end{array}$ & $\begin{array}{c}31 \\
77.5\end{array}$ & $\begin{array}{c}1 \\
2.5 \%\end{array}$ & $\begin{array}{c}0 \\
0 \%\end{array}$ & $\begin{array}{c}0 \\
0 \%\end{array}$ \\
\hline
\end{tabular}




\begin{tabular}{|l|c|c|c|c|c|}
\hline $\begin{array}{l}\text { Clarity of } \\
\text { materials in Self- } \\
\text { study VCD }\end{array}$ & $17.5 \%$ & $82.5 \%$ & $0 \%$ & $0 \%$ & $0 \%$ \\
\hline $\begin{array}{l}\text { Attractiveness of } \\
\text { materials in Self- } \\
\text { study VCD }\end{array}$ & 6 & 34 & 0 & 0 & 0 \\
\hline $\begin{array}{l}\text { Attractiveness of } \\
\text { materials/ topics } \\
\text { in student book }\end{array}$ & $17.5 \%$ & $82.5 \%$ & $0 \%$ & $0 \%$ & $0 \%$ \\
\hline $\begin{array}{l}\text { The level of } \\
\text { difficulty of } \\
\text { materials }\end{array}$ & 4 & 36 & 0 & 0 & 0 \\
\hline
\end{tabular}

On the final assessment, the teacher and the writer collaborated checking students' scores. There were two scores for each student: multiple choice, and essay. The marking system was :

Reading section : $\mathrm{n} \times 2=70$

Writing section $: \mathrm{n} \times 6=30$

Total score

$$
=100
$$

For multiple choice score, the teacher personally helped to calculate it. Because of subjectivity motives, the essay score was calculated by the teacher and the researcher, then, their scores for each student were averaged into one score only.

As indicated by the students' answers and the teacher's opinions in questionnaires, and the result of the study, the written news item text material is appropriate to grade ten students of Senior High School.Consequently, The average of students' score was 76,14 and the learning mastery was $79,55 \%$. It refers to the minimum standard score 
of SMA N 7 Semarang. However, there were 8 (22\%) students should attend the remedial teaching done by the teacher because they got under school minimum standard score for ten graders 66.

According to the aggrement of the school stake holder, the minimum standard score of passing grade of this school is minimally 66 from $80 \%$ of its students.

\section{The teacher's opinion on the materials.}

The result of the teacher's opinion through a questionnaire was:

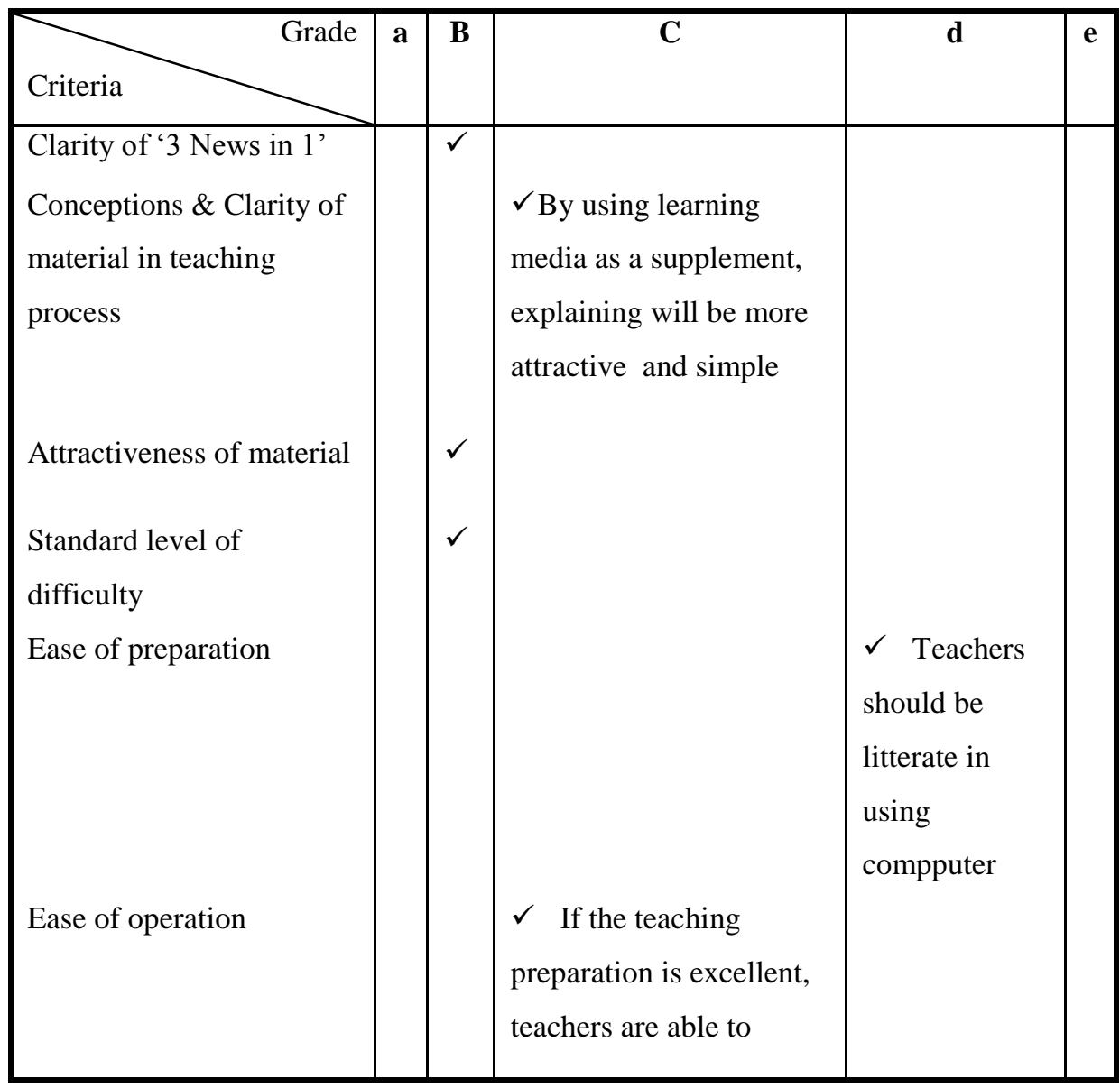




\begin{tabular}{|l|l|l|l|l|l|}
\hline & & & operate material/ use IT & & \\
Self-study VCD in & & $\checkmark$ & & & \\
students' mastery & & & & & \\
Attractiveness of Self- & $\checkmark$ & & & & \\
study VCD & & & & & \\
Teacher's manual in & & $\checkmark$ & & & \\
teaching process and Self- & & & & & \\
study VCD explanation & & & & & \\
\hline
\end{tabular}

\section{Second revision}

The material development revision comprised 'suitability with the curriculum, level of difficulty, attractiveness, effectiveness, practicality, clarity of the length, content, speed of delivery, and style of delivery criteria'. In doing so, the writer did not only refer to the first revision and the result of the tryout but also the teacher's and students' questionnaires. The first revision showed that most of the experts and teachers estimated more than adequate on the material. As the result, the material did not need to be revised.

\section{Producing the final product}

In the last part of developing material, the writer edited and revised in order to generate a better product. Thus, she carved up the themes and subthemes in her materials into three units: (1) Do you like reading news?; (2) How do you write news item text?; and (3) Evaluation. 
The final news item text material was written and finalized with some illustrations related to the theme ' 3 News in One'. There were a student book, a teacher's Guide and Self-study VCD which were all entitled " 3 News in One". The term refer to combination of news item text from 3 sources: newspapers, magazines and internet.

\section{Conclusion and recommendation}

News item texts in "KTSP (curriculum)", "competency standard or $S K$ ", and "basic competence or KD" (Depdiknas,2009:313) should be found in the printed and electronic mass media, such as newspapers, magazines and internet. Three examples of news item texts developed in this study were written news texts taken from Jakarta Post newspapers, Kangguru magazines and internet.

Based on the "KTSP", "SK", and "KD", the generic structure and linguistic features which should be discussed in the news item texts for the ten graders of Senior High School were :

a. Generic Structure:

- Newsworthy events $\quad$ : recounts the event in summary form

- Background events : elaborate what happened, to whom, in what circumstances.

- Source : comments by participants in, witnesses to and authorities expert on the event.

b. Langauge Features:

- Short telegraphic information about: story summerized in one sentence.

- Use of material processes to re-tell the story 
- Use of projecting verbal processes in source`stage ( in past tense form).

- Focus on circumstantial meaning.

In line with the conclusions of this study, the recommendations presented below may be proposed into a similar study as well as English teachers who are going to apply this material development in their classrooms. The writer provides three recommendations. Firstly, the product of this study is practical as one of prototype in developing teaching-learning material by using available sources in massmedia. Next, generally, teachers who apply the product should attempt it first before teaching-learning process. They have to confirm whether each time in reading and writing sections of each stage, the students get the point of reading comprehension and writing as well. Then specifically, further writers are able to develop material for other language skills, grades or perform spoken news item texts/ any other text-types by taking up the same model since this material development focuses on the written language and on one text-type.

\section{References}

Agustien, H.I R. 2003. KTSP: Communicative Competence. Short Paper in Semarang Senior High School English Teacher Forum (MGMP) Seminar.

Celce-Murcia, M. Z. and Dornyei, S. 1995. Communicative Competence: A A pedagogically Motivated Model Model with Content Specifications. Issued in Applied Linguistics.

Harmer, J. 2004. How to Teach Writing.Harlow: Longman.In 2007.Concise Oxford English Dictionary 11th Edition.Retrieved from http//:www.mobi-systems.com. 
Developing Written News Item Text Materials

for the Tenth Graders of Senior High School

Hyland, K. 2003. Second Language Writing. Cambridge: Cambridge University Press.

Richards, C.J. 2001. 30 Years of TEFL TESL: A Personal Reflection.SEAMEO Regional Language Centre Singapore. 